\title{
Educação sanitária, estudos de atitudes raciais e psicanálise na trajetória de Virgínia Leone Bicudo*
}

\author{
Marcos Chor Maio**
}

Na ficha funcional de Virgínia Leone Bicudo (1910-2003) da Escola Livre de Sociologia e Política (ELSP) consta que ela foi contratada em março de 1940, ingressando na instituição com trinta anos incompletos. Filha de Joana Leone, imigrante pobre de origem italiana, e de Teófilo Bicudo, descendente de escravo e afilhado de fazendeiro de café em Campinas. O padrinho de Teófilo, Bento Augusto de Almeida Bicudo, foi senador pelo Partido Republicano Paulista (PRP), positivista e fundador do jornal O Estado de São Paulo. Virgínia Bicudo foi identificada como "branca" em seu documento de trabalho. ${ }^{1}$ A cor atribuída a

\footnotetext{
* Recebido para publicação em julho de 2010, aceito em setembro de 2010. Agradeço à Mariana Damasco, que integra o projeto Faperj (E26/110.461/2010), sob a minha coordenação, pela pesquisa que redundou neste trabalho. Sou ainda grato aos comentários e sugestões feitas ao texto por Marcia Regina Barros da Silva e Nemuel da Silva Oliveira.

** Sociólogo, Doutor em Ciência Política, professor do Programa de PósGraduação em História das Ciências e da Saúde da Casa de Oswaldo Cruz (Fiocruz) e pesquisador CNPq. maio@coc.fiocruz.br

1 Virgínia Leone Bicudo. Documentos Diversos, CEDOC-FESPSP; http://almanaque.info/ProvinciaSP/PROVINCIASP.htm;

http://www.al.sp.gov.br/web/legislativo/parlamento/capitulo2/parte11.pdf, acessado em 23/03/2010. Os avós maternos de Virgínia Bicudo vieram da Sicilia (Itália) para o Brasil no fim do século XIX, no contexto da grande leva de imigração italiana. Trabalharam em Campinas, na fazenda de café do coronel Bicudo. O pai morou e trabalhou na fazenda do coronel Bicudo, sendo tratado como filho pelo coronel. A mãe, Joana, foi babá da filha de criação do coronel. Na fazenda, Teófilo e Joana se casaram. Posteriormente, Teófilo foi estudar em
} 
Entrevista Virgínia Leone Bicudo

Bicudo revela uma das faces da ideologia do branqueamento no Brasil, em que a aparência de um indivíduo com marcas de origem africana poderia ser atenuada em função do grau de instrução, ocupação, aparência, entre outras características (Nogueira, 1955:460). Nos anos 1930, ela já pertencia a uma família de classe média.

No "Registro de Empregado", Virgínia Bicudo aparece como professora de Higiene Mental e Psicanálise da ELSP, residente no Jardim Paulista. Havia deixado no passado o Bairro da Luz, na Rua São Caetano, a Vila Economizadora, conjunto de habitações construídas no final do século XIX que abrigava funcionários públicos, imigrantes e operários. Lá morou com os pais e cinco irmãos. Seu pai, Teófilo, contou com o apoio financeiro do Coronel Bicudo, quando se transferiu para a cidade de São Paulo a fim de realizar sua formação escolar. Estudou no tradicional Ginásio do Estado e ingressou, por influência política do padrinho, nos Correios e Telégrafos, onde veio a se tornar alto funcionário. Em 1933, a morte de Teófilo levou a primogênita a assumir a responsabilidade pelo sustento da família. ${ }^{2}$

Da Luz ao Jardim Paulista, eis a circulação de Bicudo pela geografia da cidade espelhando o processo de mobilidade social mediante a educação, espaço privilegiado no qual as mulheres de classe média começaram a ascender ao mundo das profissões de maior reconhecimento social. Em 1930, após estudar na Escola do Brás e no Ginásio do Estado, ela concluiu o curso secundário na tradicional Escola Normal Caetano de Campos. Em seguida, exerceu o magistério na categoria de "professora substituta permanente" nos Grupos Escolares Carandiru e Consolação. ${ }^{3}$

São Paulo, por decisão de Bento Bicudo. Entrevista de Rosa Zingg, sobrinha de Virgínia Leone Bicudo, a Marcos Chor Maio. São Paulo, 17/12/2009.

2 Entrevista de Rosa Zingg a Marcos Chor Maio. São Paulo, 17/12/2009.

3 Esta informação me foi concedida pela psicanalista Maria Ângela Moretzsohn, da Divisão de Documentação e Pesquisa da História da Psicanálise da Sociedade Brasileira de Psicanálise de São Paulo (SBPSP). 
Bicudo foi chamada a lecionar em escola rural de Maranduba (Ubatuba), mas acabou seguindo outro destino ingressando no Curso de Educadores Sanitários do Instituto de Higiene de São Paulo (Faria, 2007). Assim, Bicudo seguiu a orientação de seu pai, que nutria a expectativa que a filha ascendesse socialmente por meio da instrução. Em seguida à prova de seleção em janeiro de 1932, Virgínia matriculou-se no referido curso vindo a pertencer à turma composta por 30 alunos (27 mulheres e 3 homens), sendo 28 deles professores e majoritariamente do interior. ${ }^{4}$

Educadora sanitária, visitadora psiquiátrica, cientista social, professora universitária, psicanalista, divulgadora científica, protagonista de diversas iniciativas no plano da institucionalização da psicanálise no Brasil, eis o mundo diverso em que Bicudo transitou. Considero, a partir das marcas de sua trajetória, que Virginia Bicudo concebe o conflito como parte constitutiva da vida social. Um dos casos exemplares desta visão encontra-se na sua dissertação de mestrado Estudo de Atitudes Raciais de Pretos e Mulatos em São Paulo defendida na ELSP em 1945. ${ }^{5}$ Os achados sociológicos de Virgínia Bicudo interpelam visões tradicionais dos anos 1940 e 1950, que concebem a existência de harmonia racial e interpretam o preconceito de cor como subsumido ao de classe. Nesse sentido, o trabalho pioneiro de Bicudo ao lado das pesquisas realizadas por Oracy Nogueira revela o protagonismo $e$ a atualidade dos estudos sobre as relações raciais no Brasil realizados pela Escola Livre de Sociologia e Política.

\footnotetext{
4 Sobre Teófilo Bicudo, ver entrevista de Virgínia Bicudo que vem a seguir. Lista de alunos da turma de 1932 do Curso de Educadores Sanitários. Centro de Memória da Faculdade de Saúde Pública da Universidade de São Paulo.

5 A dissertação de mestrado de Virgínia Bicudo foi publicada recentemente em livro com o mesmo título do seu artigo, que apareceu na revista Sociologia (Bicudo, 1947). Ver: Bicudo (2010).
} 
Entrevista Virgínia Leone Bicudo

\section{Da Educação Sanitária às Ciências Sociais}

Criado em 1925, o Curso de Educadores Sanitários do Instituto de Higiene estava voltado para professores primários devido à longa duração do curso de enfermagem e à falta de profissionais formados nessa área em São Paulo. A partir de uma visão preventiva, os educadores ministravam conhecimentos teóricos e práticos de higiene em escolas e centros de saúde (Faria, 2006:181). A criação do curso coincidiu com um momento de crescente profissionalização das mulheres das classes médias urbanas. As políticas educacionais entre as décadas de 1920 e 1940 foram fundamentais à inserção gradativa das mulheres no campo profissional e acadêmico. As mudanças no sistema escolar, associadas às transformações mais amplas - como a urbanização $e$ a industrialização - contribuíram para a redefinição dos papéis sociais femininos nos centros urbanos da época. A expansão progressiva da economia impulsionou as atividades das mulheres para fora do mundo do trabalho doméstico (Azevedo \& Ferreira, 2006:217-220). Desse modo, a presença das mulheres no curso de educadores sanitários e nos serviços de saúde representou um novo patamar no universo social feminino (Rocha, 2005). Ao concluir o curso de um ano, em 1932, e realizar estágio no primeiro semestre de 1933, Virgínia foi contratada pela diretoria do Serviço de Saúde Escolar do Departamento de Educação para dar aulas de higiene em educandários da cidade de São Paulo (Zingg, 2009).

Em 1936, ela ingressou no curso de graduação em Ciências Políticas e Sociais da Escola Livre de Sociologia e Política (ELSP). As ciências sociais passaram a ser uma das alternativas profissionais emergentes para as mulheres ${ }^{6}$ e, no caso de Virgínia, permitiram o aprofundamento da visada sociológica adquirida no âmbito da educação sanitária, na estreita relação entre

6 Sobre a presença feminina nos cursos de Ciências Sociais em São Paulo nos anos 1940 e 1950, ver: Anuários da ELSP e Miceli, 1989. 
puericultura e condições de vida, inclusive na chave eugênica positiva, dominante nos anos 1920 e 1930 no Brasil (Hochman et alii, 2010). Não por acaso, Maria Antonieta Castro - aluna da primeira turma do Curso de Educadores Sanitários do Instituto de Higiene (1925), Educadora-Chefe da Inspetoria de Educação Sanitária e Centros de Saúde do Serviço Sanitário do Estado de São Paulo, e única representante feminina a apresentar trabalho no Primeiro Congresso Brasileiro de Eugenia, em 1929 - afirmava que:

(...) a grande extensão territorial de nosso país está a pedir maior interesse para a salvaguarda da infância por parte dos higienistas e administradores, constituindo (...) a cultura da criança, um verdadeiro problema econômico social de tanto mais difícil solução quanto de mais perto visado (Castro, 1929:3).

No evento, Antonieta expressou preocupação pró-natalista, uma das características do ideário nacionalista ao longo de décadas no Brasil, associada à chave sociológica avessa a determinismos climáticos ou raciais.

Trazendo sua experiência sanitarista, Virgínia se matriculou em 1936 na ELSP, primeira instituição acadêmica de Ciências Sociais criada no Brasil (1933), fruto dos esforços intelectuais de setores da elite paulista que buscavam alternativas políticas, a partir da formação de quadros técnicos, à derrota da Revolução Constitucionalista de 1932. As Ciências Sociais tornam-se importante fonte de conhecimento para as incipientes organizações de planejamento econômico e desenvolvimento social (Limongi, 1989; Kantor et alii, 2001). Sob os auspícios da ELSP, foram realizados estudos sobre o negro; padrão de vida $e$ assistência filantrópica na cidade de São Paulo; enquetes sobre preconceito e atitudes raciais; pesquisas de opinião pública, imigrantes, condições de trabalho e personalidade dos operários; higiene mental e psicanálise; experiência social de doenças; 
Entrevista Virgínia Leone Bicudo

estudos de comunidades rurais; projetos de desenvolvimento de comunidade, etnologia indígena, etc. ${ }^{7}$

Para contemplar o amplo e diversificado leque temático de suas pesquisas, a ELSP, sob ascendência norte-americana, contratou sociólogos e antropólogos estrangeiros, tais como: Horace Davies, Samuel Lowrie, Donald Pierson, Radcliffe Brown, e recebeu a visita temporária de outros: Franklin Frazier, Melville Herskovits, Charles Wagley. Inspirando-se na Escola Sociológica de Chicago, a ELSP adotou perspectiva interdisciplinar como nas relações entre Antropologia e Sociologia ou Sociologia, Antropologia e Psicologia Social. Fez dos problemas urbanos e rurais seus laboratórios.

O bacharelado da ELSP tinha a duração de três anos e, no período em que Virgínia foi aluna da Escola, a grade curricular era composta das seguintes disciplinas: Biologia Social, Economia Social, Estatísticas, Introdução à Economia, Sociologia, Ciência Política, Contabilidade, Economia Internacional, Finanças Públicas, História das Doutrinas Econômicas, Psicotécnica, Administração Pública, Contabilidade, Economia Internacional, Educação Nacional, Finanças Públicas, História Econômica do Brasil e Psicologia Social. Segundo relato de Virgínia, foi durante as aulas da educadora e psicóloga Noemy da Silveira Rudolfer, em 1937, que ela manifestou interesse pela psicanálise. Ao resenhar o livro Psicologia para Estudantes de Educação (1935) de Arthur Irving Gates ${ }^{8}$, professor do Teachers College (Columbia

\footnotetext{
7 Ver Anuários da Escola Livre de Sociologia e Política. Os temas que figuraram nos estudos realizados pela ELSP apontam diversas interfaces entre medicina $e$ sociologia entre os anos de 1930 e 1950. Como lembra Silva (2003:77-79), professores da Escola Paulista de Medicina, como Pacheco e Silva, Andre Dreyfus e Walter Leser, assinaram o manifesto de fundação da ELSP e ministraram disciplinas na instituição.

8 Trata-se de livro publicado pela Editora Acadêmica, traduzido por Noemy da Silveira Rudolfer, Chefe do Laboratório de Psicologia do Instituto de Educação da Universidade de São Paulo e Professora-catedrática de Psicologia Social da Escola Livre de Sociologia.
} 
University), chamou-lhe a atenção um artigo sobre sublimação baseado nas idéias de Freud (Candiota, 1977; Bicudo, 1989). Nesse contexto, ela conheceu o médico Durval Marcondes, uma das principais autoridades no campo da psicanálise na época. ${ }^{9}$

Durval atuava no Serviço de Saúde Escolar desde meados da década de 1920 e começou a ministrar a disciplina Higiene Mental para o Curso de Educadores Sanitários em 1937. No ano seguinte, criou o Serviço de Higiene Mental Escolar (SHME) da Secretaria de Educação do Estado de São Paulo, ocasião em que Virgínia Bicudo tornou-se visitadora psiquiátrica. O SHME funcionava por intermédio das clínicas de orientação infantil, cujas funções eram a prevenção e o tratamento de problemas psíquicos da criança (Bicudo, 1941). Ainda em 1938, Virgínia bacharelou-se em Ciências Sociais e Políticas sendo a única mulher formada numa turma de 10 alunos.

No início da década de 1940, Bicudo passou a lecionar, ao lado de Durval Marcondes, as disciplinas Higiene Mental e Psicanálise na ELSP. Essa parceria profissional e intelectual contribuiu para a transformação da instituição acadêmica, entre os anos 1930 e 1950, num importante espaço de difusão e de institucionalização dos "saberes psi" no Brasil. ${ }^{10}$

Marcondes e Bicudo tinham outro elo em comum: a psicanalista alemã e judia Adelheid Koch, refugiada do nazismo. Ele a conheceu em 1936 e Bicudo tornou-se a primeira mulher a ser analisada por Kock, a partir de 1937. Na primeira metade dos anos 1940, sob a liderança de Koch, Virgínia pertenceu ao primeiro grupo de formação psicanalítica organizado em São Paulo ${ }^{11}$, do qual participaram o engenheiro Frank Phillips e os

9 Sobre as relações entre o psicanalista Durval Marcondes e o Movimento Modernista, ver Facchinetti, 2001.

${ }^{10}$ Nos anos 1930, a ELSP teve a disciplina Psicologia Social ministrada por Raul Briquet, Noemy Rudolfer e Aniela Ginsberg. Sobre a história dos "saberes psi", ver: Duarte et alii, 2005.

${ }^{11}$ Ele era conhecido como "Grupo Psicanalítico de São Paulo" (1944). Em 1945, tornou-se Sociedade Brasileira de Psicanálise de SP (Abrão, 2010). 
médicos Flávio Dias e Darcy de Mendonça Uchoa. Koch se encarregou da análise didática, das supervisões e dos estudos teóricos e técnicos dos candidatos a analistas, que foram também seus primeiros pacientes no Brasil (Bicudo, 1989; Sagawa, 2002).

Em várias entrevistas, Bicudo fala em "sofrimento" como um importante motivo para sua opção pelo curso de Ciências Sociais na ELSP, "imaginando que lá (...) descobriria as causas da dor e, portanto, o lenitivo" (Bicudo, 1989:95). Em alguns depoimentos, ela revela que foi alvo de preconceito na infância pelo fato de ser negra, chegando ao dramático relato sobre um episódio de discriminação racial sofrido pelo pai, presente na entrevista que vem a seguir. ${ }^{12}$

Virgínia Bicudo transformou a experiência social e individual do preconceito de cor em reflexão acadêmica no mestrado, ao nomeá-la como "questão racial". Em arguta análise sociológica, ela antevê interpretações realizadas apenas na década de 1950, no contexto do ciclo de pesquisas sobre as relações raciais Brasil, patrocinado pela UNESCO.

\section{Na fronteira da Sociologia com a Psicologia Social: o estudo de atitudes raciais na ELSP}

Em 1942, Bicudo ingressou na recém-criada Divisão de Estudos Pós-graduados da ELSP, coordenada pelo sociólogo

12 O psicanalista Paulo Cesar Sandler lembra o comentário de Bicudo: "Desde pequenina eu fui vista como uma 'negrinha pobre'. Quando cresci, meu crime foi ser mulher emancipada" (Sandler, 2004:29). Em depoimento a Meyer (2004:1718), Bicudo recordou que: "Eu fui criada fechada em casa, quando eu saí foi para ir à escola e foi quando pela primeira vez, na escola, a criançada começou: 'negrinha, negrinha'. Quando eu estava dentro de casa eu nunca tinha ouvido. Então eu levei um susto". Virgínia Bicudo também expôs a motivação sociológica para o ingresso na ELSP, com base em sua vivência do preconceito de cor: "Desde criança eu sentia preconceito de cor. Queria o curso de Sociologia porque, se o problema era esse preconceito, eu deveria estudar Sociologia para me proteger do preconceito, que é formado ao nível sociocultural" (Bicudo, 1994:6). Damasceno (2010:12) aponta para a importância dos estudos sobre os intelectuais negros. 
norte-americano Donald Pierson (1900-1995). Sob a orientação de Pierson, ela se interessou pelos "estudos de atitudes", na confluência da Sociologia com a Psicologia social. Inicialmente, seu projeto de pesquisa se intitulava "Estudo da Consciência de Raça entre Pretos e Mulatos de São Paulo"13, que revelava o interesse da socióloga pelo tema das tensões raciais. Indicava ainda a proposta comparativa implícita com o caso baiano, pesquisado por Pierson.

O tema das relações étnicas e raciais adquiriu maior visibilidade na agenda de pesquisas da ELSP no início dos anos 1940 com os estudos acerca "da competição entre diferentes "cores' e nacionalidades" e "sobre atitudes raciais entre brancos e negros em São Paulo", utilizando questionários, entrevistas e histórias de vida. ${ }^{14}$ A ELSP estava em sintonia com as transformações urbano-industriais que vinham ocorrendo na cidade inspirando-se nos estudos sociológicos sobre Chicago.

Dos três alunos (Virgínia Bicudo, Gioconda Mussolini e Oracy Nogueira) da primeira turma do mestrado da ELSP (19421945), Bicudo e Nogueira realizaram pesquisas sobre atitudes raciais, chegando a conclusões distintas do orientador Donald Pierson. Nogueira elaborou dissertação sobre o estigma na experiência social de tuberculosos, na qual se encontram os temas das atitudes sociais e dos estereótipos (Nogueira, 2009 [1950]). Publicou, durante o curso de graduação, artigo sobre o preconceito de cor com base em investigação sobre atitudes desfavoráveis de anunciantes de São Paulo ao contratarem "trabalhadores de cor" a partir de anúncios de procura e oferta de emprego do jornal Diário Popular.

${ }^{13}$ Carta de Donald Pierson a Virgínia Bicudo, 21/08/1942, 1p. Acervo Virgínia Leone Bicudo, Divisão de Documentação e Pesquisa da História da Psicanálise da SBPSP.

${ }^{14}$ A Tentative Outline of Expenditures for Research and Translations in Connection with the Grant of the Rockefeller Foundation for the Year 1941, 3p. Acervo Donald Pierson. Arquivo Edgard Leuenroth (AEL)/UNICAMP. 
Entrevista Virgínia Leone Bicudo

Quanto à natureza das atitudes adversas aos negros em São Paulo, esta não se limitaria ao "preconceito de raça" tampouco ao "preconceito de classe". Nogueira sugere uma "terceira via", o preconceito de cor, que seria um "tipo de preconceito intermediário", uma espécie de intersecção entre cor e classe, não se confundindo com o de estrato racial, próprio ao modelo norteamericano, no qual a ascendência negra, mesmo que longínqua, definiria a identidade racial do indivíduo, nem com o preconceito de classe, na medida em que negros e pardos localizados em posições sociais elevadas na estrutura social não estariam imunes a atributos negativos preconcebidos derivados da cor (Nogueira, 1942:357; Cavalcanti, 1996; Maio, 2008). Diferente da chave interpretativa piersoniana, que privilegia o preconceito de classe, ele afirma que processos de ascensão social não cancelam as marcas raciais. Em seu estudo sobre atitudes raciais, Bicudo apresenta afinidades com o trabalho de Nogueira.

Durante o mestrado (1942-1945), Bicudo fez diversas disciplinas que abordavam aspectos sócio-antropológicos sobre as relações étnico-raciais. ${ }^{15} \mathrm{Na}$ dissertação, ela aborda tema concernente à tradição das ciências sociais brasileiras, do persistente exercício de reflexão sobre os problemas e desafios recorrentes da sociedade em se constituir enquanto uma nação moderna. O negro como questão é analisado nos anos $1940 \mathrm{em}$ contexto no qual as inquietudes intelectuais sobre nossa sociedade passam a ser vistas mediante a crítica ao ensaísmo e pela afirmação de uma rigorosa produção do conhecimento científico no âmbito da incipiente institucionalização das ciências sociais no

${ }^{15}$ As disciplinas e as notas alcançadas por Bicudo foram: Raça e Cultura (9); Negro no Brasil (9 e 1/4); Etnologia Brasileira (9,0); Assimilação e Aculturação $(6,0)$; Princípios de Antropologia Social $(6,0)$; Estudos da Sociedade $(9,0)$; Métodos nas Ciências Sociais (9,0); Introdução à Antropologia Social $(7,0)$. Carta de Donald Pierson a Virgínia Bicudo, 18/05/1944, 1p. Acervo Virgínia Leone Bicudo, Divisão de Documentação e Pesquisa da História da Psicanálise da SBPSP. 
Brasil, especialmente em São Paulo e no Rio de Janeiro (Vilhena, 1997:134-135).

Na dissertação sobre a "questão racial" (Bicudo, 1945:2), intitulada Estudo de Atitudes Raciais de Pretos e Mulatos em São Paulo, Bicudo combina análise sociológica (estrutura de classes, mobilidade social, status, valores sociais, preconceito de cor) com psicologia social ("atitudes sociais"). Converge assim para sua formação em Ciências Sociais associada aos estudos $e$ experiências no campo da psicanálise. Na trilha de Pierson, ela escolheu tema frequentado desde as primeiras décadas do século $\mathrm{XX}$ pelo Departamento de Sociologia da Universidade de Chicago, a exemplo do estudo clássico de Thomas e Znaniecki (1918), em que abordam processos de ajustamento dos imigrantes poloneses nos EUA. Esse fenômeno, traduzido por expressivas mudanças culturais, foi analisado na interseção entre valores coletivos $e$ atitudes individuais, ressaltando a dimensão subjetiva nas interações sociais. Nesse momento, as pesquisas sobre atitudes raciais (preconceitos e estereótipos) enfatizavam as críticas ao determinismo biológico, ao suposto caráter inato das ações humanas, buscando as razões psico-sociológicas das hostilidades entre grupos sociais - étnicos, religiosos, econômicos, etc. (Klineberg, 1940:346-347). Em sintonia com essa perspectiva, Robert Park concebe as atitudes a partir de motivações econômicas, religiosas, de busca de status ou suscitadas pela discriminação a minorias, entre outras (Park, 1931:31).

Além de Park, Bicudo se inspira em outro sociólogo da Universidade de Chicago, Ellsworth Faris, que entende a atitude dos indivíduos a partir de determinados objetos que, no caso da professora da ELSP, é o preconceito. Na perspectiva de Faris (1937:9-11), as atitudes deveriam ser analisadas em momentos de crise, pois revelam períodos de desorganização social. Ele segue interpretação de Park que concebe as atitudes como expressão de momentos de tensão, de transformação social. Na chave interpretativa de Park, "as mudanças sociais começam com as mudanças nas atitudes condicionadas pelos indivíduos, operando- 
Entrevista Virgínia Leone Bicudo

se posteriormente mudanças nas instituições e nos 'mores'" (Bicudo, 1945:2; Park, 1931: 27 e 43).

A pesquisa de Virgínia Bicudo foi realizada entre 1941 e 1944, durante o Estado Novo e ao longo da Segunda Guerra Mundial. Utilizou, em parte, sua experiência como visitadora psiquiátrica, que já vinha abordando criticamente, embasada em histórias de vida, os casos das "chamadas "crianças-problema", (Bicudo, 1942a:42-43), alvos de preconceito ao serem transformadas em "crianças escorraçadas (...) crianças estigmatizadas como perversas" (Bicudo, 1942b:23). Elas seriam um fenômeno sociológico e psíquico derivado das tensões familiares, do contexto social.

O trabalho como visitadora psiquiátrica é pautado por tensões, preconceitos e marginalização social. Ele encontra-se distante do consenso. A prática profissional influenciou a perspectiva sociológica de Bicudo ao conceber um mundo marcado pelo conflito social. Essa visada ganhou refinamento sócio-antropológico na ELSP, especialmente no mestrado.

Em sua investigação, ela utilizou basicamente o estudo de caso e a entrevista. Orientou-se pelos estudos de Pierson (1942), Stonequist (1937), Nogueira (1942) e artigos sobre "atitudes sociais" de Park e Faris. Elegeu relatos de pais de alunos de escolas públicas, residentes em quatro bairros populares (Bela Vista, Santana, Barra Funda e Mooca) e um de classe média (Vila Mariana). As entrevistas foram realizadas com familiares que frequentavam a Clínica de Orientação Infantil, da Seção de Higiene Mental da Secretaria de Saúde do Estado de São Paulo. Constaram ainda do conjunto de depoentes ${ }^{16}$ ex-militantes da Frente Negra Brasileira (FNB), organização política de ampla visibilidade nos anos 1930 em São Paulo, que foi colocada na ilegalidade pelo governo estadonovista, assim como outras

${ }^{16}$ Foram realizadas mais de 30 entrevistas (Bicudo, 1945:3). 
organizações da sociedade civil (Andrews, 1991, 148-156). Bicudo pesquisou também o jornal da FNB: Voz da Raça. ${ }^{17}$

A pesquisadora utilizou duas variáveis para qualificar seu universo: cor e classe social. Selecionou aspectos da aparência física, sendo que os pretos ${ }^{18}$ foram classificados pela cor, pelos cabelos "encarapinhados" e pelos pais que exibiam semelhantes características. O princípio classificatório para os entrevistados mulatos foi um dos pais ser preto e outro branco, ou um pardo $e$ outro branco, ou ambos pardos. Em termos de classe social dos depoentes, as variáveis foram renda, profissão $e$ instrução. (Bicudo, 1945:5). ${ }^{19}$

Bicudo verificou que os negros de menor poder aquisitivo apresentavam atitudes de maior rejeição em relação aos próprios negros e mulatos quando comparados com os brancos. Alguns entrevistados declararam não haver união entre os negros, pois eram "invejosos e competitivos". Outros afirmaram ser mais bem tratados por brancos do que por negros. De acordo com a análise dos relatos, tais atitudes de rivalidade entre os pretos e de convívio mais harmonioso destes com os brancos estariam calcadas no sentimento de inferioridade dos negros suscitado pelo grupo dominante. Ao perceberem os brancos como mais simpáticos, os negros das camadas populares seriam movidos por um mecanismo de evitação do conflito com os brancos e assim

17 Bicudo deu nomes fictícios a FNB, denominada "Associação dos Negros Brasileiros", e o jornal Voz da Raça, intitulado "Os Descendentes de Palmares". Uma das razões para o uso dessas denominações diz respeito ao contexto político autoritário em que Bicudo realizou a pesquisa.

${ }^{18}$ Em "Estudo de Atitudes entre Pretos e Mulatos em São Paulo", Bicudo utiliza predominantemente as categorias: preto, mulato e branco. $\mathrm{Na}$ análise da pesquisa de Virgínia Leone Bicudo, usei predominantemente os termos negro, mulato e branco.

${ }^{19}$ No caso da educação, os critérios foram: 1) até o curso primário completo para as camadas populares; 2) o curso secundário para os setores médios. Em termos de renda familiar, Bicudo definiu acima de $\operatorname{Cr} \$ 500,00$ o perfil de classe média, e menos de Cr\$500,00 as classes populares (Bicudo, 1945:5). 
Entrevista Virgínia Leone Bicudo

produziriam uma compensação ao sentimento de subalternidade (id.ib:63).

Em relação aos negros das camadas médias, as atitudes raciais apareceram com maior ênfase, na medida em que os entrevistados seriam alvos mais visíveis do preconceito de cor. Um deles, criado por brancos e com curso secundário, chegou a colocar em dúvida a citação do sociólogo Donald Pierson: "Afirma-se na Bahia, como fez o professor Pierson, que o negro rico não sofre preconceitos. Tal afirmação não é verdadeira em São Paulo" (id.ib:9). O depoente contou que passara por diferentes situações de preconceito no cotidiano, a saber: não ser convidado para festas na casa de amigos brancos, sofrer restrições na entrada em restaurantes da elite e não conseguir namorar mulheres brancas ou mulatas por oposição das familias (id.ib:1020). Os negros das classes médias têm ressentimento e são pessimistas quanto à possibilidade de haver solidariedade entre brancos e negros. Estes, segundo Bicudo, pertencentes aos estratos médios enfrentavam o sentimento de inferioridade, provocado pelas atitudes de preconceito dos brancos, mediante determinados meios de ascensão social, tais como: o casamento, o exercício de profissões liberais e da "boa aparência" (id.ib:22). Mesmo quando ascendiam profissionalmente ou conseguiam um diploma de nível superior, eles continuavam a sofrer constrangimentos no meio social branco, provocando, desse modo, a consciência de cor (id.ib:21-22). Reforçando a crítica de seu depoente a Pierson, Virgínia considera São Paulo um contraponto à experiência baiana. Ela pondera que no caso paulista

talvez mais acentuadamente do que na Bahia, a posição ocupacional inferior do negro incluiria aspectos da luta no nível de status social, isto é, com mais dificuldades venceriam os méritos pessoais, por que encontrariam maior resistência como negros (id:ib:42). 
De acordo com Bicudo, entre os mulatos das camadas populares se observa consciência de cor mais acentuada do que entre os pretos do mesmo estrato social, pois manifestam atitudes de evitação, receosos de serem chamados de negros. Nos depoimentos, ficou evidente o desejo das mulatas das classes baixas de procurarem cônjuges da mesma cor, pois não desejavam se unir a negros e tampouco sofrer preconceito por terem se casado com brancos (id.ib:30).

No caso das atitudes dos mulatos das classes médias, os depoimentos demonstrariam a presença do sentimento de inferioridade. Na visão de Bicudo, eles ansiavam a condição de serem reconhecidos como brancos, na medida em que estavam conscientes de que a cor era uma barreira à ascensão social (id.ib:36-37).

Virgínia Bicudo se inspira em Nogueira (1942) ao considerar que o mulato procurava adquirir símbolos do grupo branco dominante, consciente de que a discriminação estaria na razão direta da associação de sua cor com a origem africana. Esse era um indicador preciso da existência no Brasil de "um preconceito de cor, distinto do preconceito de raça ou de classe" (id.ib:38).

$\mathrm{Na}$ segunda parte da dissertação, Bicudo aborda, como mencionado acima, a Frente Negra Brasileira (FNB) através de entrevistas com militantes e análise de exemplares do jornal Voz da Raça. A instituição era fruto da mobilização dos estratos sociais médios que creditavam à "barreira de cor" as condições adversas vividas pelos negros na sociedade brasileira. Percebendo que o confronto com o branco ampliava sua reação contra o negro, a liderança do movimento negro mudou de estratégia. $\mathrm{O}$ objetivo da FNB era criar uma solidariedade entre os negros para a luta "contra os obstáculos à ascensão social em consequência da cor" (id.ib:47). Por meio da educação, do trabalho, da valorização profissional e da ação política, os negros seriam reconhecidos pelo grupo branco dominante (id.ib.).

$\mathrm{Na}$ conclusão, Bicudo observa que quanto mais o negro ascende social e economicamente, maior é a possibilidade de 
Entrevista Virgínia Leone Bicudo

ocorrer consciência racial. Concordando aparentemente com Pierson quanto à chance de pessoas de cor atingirem os estratos médios, reconhecendo assim a importância do preconceito de classe, Virgínia apresenta, simultaneamente, ponto de vista radicalmente distinto do sociólogo em face da questão da consciência racial dos negros. Em Brancos e Pretos na Bahia, Pierson conclui que "existe preconceito no Brasil, mas é preconceito antes de classe que de raça, apesar de estar, até certo ponto, ligado à cor" (1945:421). No capítulo "'Ideologia Racial' e Atitudes Raciais", ele constata, com base em pesquisa de fontes orais e documentais realizada em Salvador, a reduzida atenção conferida ao conflito racial ou ao seu controle pela sociedade baiana (id.ib.:269-70). As atitudes raciais são caracterizadas por uma série de estereótipos, especialmente quanto aos mulatos e aos negros. Pierson

identifica a sociedade baiana como constituída em classes, em que a competição toma antes a forma de luta entre as classes (que por motivo de ordem histórica vieram a coincidir em considerável extensão com a cor) que de luta entre as raças ou cores em si mesmas (Ib.id: 295-296).

Os negros que conseguem alcançar certo status social, segundo o sociólogo, tendem a ser incorporados ao grupo dominante branco. Assim, a consciência racial dos negros baianos seria mínima, pois as atitudes estariam no âmbito da chave classista.

Desde o título original de sua dissertação, "Estudo da Consciência de Raça entre Pretos e Mulatos de São Paulo" (1942), Virgínia indica a importância da análise do conflito social e do racismo. Os esforços de pretos e mulatos pela conquista de novo status social, mediante investimentos em educação e formação profissional, não levariam à eliminação "das distâncias sociais na linha de cor", devido à persistência do preconceito de cor (Bicudo, 1945:65). As tensões sociais entre brancos e negros seriam mais 
explícitas tendo em vista as barreiras raciais impostas aos negros dos setores médios que procurariam ascender socialmente.

Os achados sociológicos de Virgínia Bicudo guardam afinidades com estudos desenvolvidos somente nos anos 1950, no âmbito do "projeto UNESCO de relações raciais". Os limites à ascensão social de negros de classe média produziram movimentos sociais a exemplo da FNB e processos de afirmação de identidades raciais como caminho à superação das "barreiras de cor". Assim como Bicudo, inclusive com um capítulo intitulado "Atitudes, Estereótipos e Relações Raciais", o sociólogo Luiz de Aguiar Costa Pinto (O Negro no Rio de Janeiro, 1953), chegou a conclusão semelhante à cientista social ao analisar a atuação do Teatro Experimental do Negro na virada dos anos 1940 para os anos $1950 .^{20}$

No final da $2^{\text {a }}$ Guerra Mundial, Virgínia Bicudo apresentou reflexão inovadora ao considerar cor como importante variável na produção de desigualdades sociais em contexto intelectual no qual prevalecia a máxima de que o preconceito de classe seria reinante na sociedade brasileira.

\section{Virgínia Bicudo no Projeto UNESCO}

Ao concluir a primeira dissertação de mestrado sobre a "questão racial" defendida em uma instituição universitária brasileira, Bicudo continuou lecionando na ELSP e exercendo suas atividades de visitadora psiquiátrica e psicanalista. Em 1945, ela conheceu o psicólogo social Otto Klineberg, da Columbia University, que chegara dos EUA, em 1945, com a missão a um só tempo de trazer a experiência norte-americana no campo da psicologia social para o Brasil, e de criar o Departamento de

${ }^{20}$ Além do trabalho de Costa Pinto (1953), o estudo de Bicudo (1945) se aproxima da pesquisa de Nogueira (1955) e se diferencia da análise de Fernandes \& Bastide (1955). Esta última concebe as assimetrias raciais a partir das desigualdades sociais. Sobre as diferentes perspectivas presentes no "projeto UNESCO", ver: Maio, 1997; sobre Costa Pinto, ver: Maio, 2009. 
Entrevista Virgínia Leone Bicudo

Psicologia da USP. Bicudo assistiu ao "Seminário de Psicologia Social" 21 oferecido por Klineberg na Faculdade de Filosofia Ciências e Letras da USP, em 1946. Foi ainda convidada a participar do livro Psicologia Moderna, organizado pelo psicólogo canadense, durante a estada de Klineberg no Brasil entre 1945 e 1947. Essa obra, publicada em 1953, teve o propósito de estimular o desenvolvimento da psicologia no Brasil em diálogo com outros campos disciplinares. A coletânea contou com a colaboração de pesquisadores oriundos da Antropologia, Psicologia Social, Sociologia, Educação, Higiene Mental e Psicanálise. ${ }^{22}$ Eles estavam vinculados à USP, ELSP, PUC-SP, Faculdade Nacional de Filosofia (RJ) e diversos institutos de educação, psicologia $e$ psiquiatria de São Paulo, revelando assim a rede intelectual $e$ institucional tecida por Klineberg. Nesse período, foi criada a Sociedade de Psicologia de São Paulo.

Em 1949, Bicudo participou de uma pesquisa sobre problemas do trabalho fabril, abordando-os nas interfaces entre a sociologia e a psicologia social. A investigação foi patrocinada por um convênio entre a ELSP e o Serviço Social da Indústria (SESI). Com a colaboração dos pesquisadores Rodolfo Lenhard e Olinda Sampaio, Virgínia analisou o ambiente de trabalho do mestre de indústria em duas fábricas de São Paulo e a sua relação com os subordinados e colegas de profissão. Para isso, trabalhou com o

${ }^{21}$ A partir de 1945, Bicudo tornou-se professora-assistente da cadeira de Higiene Mental da Faculdade de Higiene e Saúde Pública da Universidade de São Paulo. Em 1946, começou a ministrar o curso de Higiene Mental na Faculdade de Enfermagem, anexa à Faculdade de Medicina da USP. Deu aulas de Higiene Mental do Trabalho no Curso de Organização Racional do Trabalho promovido pelo de Organização Racional do Trabalho (IDORT), além de participar do curso de Higiene Mental patrocinado pela Legião Brasileira de Assistência (LBA). Virgínia Leone Bicudo. Documentos Diversos, CEDOC-FESPSP.

22 O livro Psicologia Moderna (1953) contém artigos que tratam de tópicos como Cultura e Personalidade, Diferenças Individuais e Grupais, Atitudes e Opiniões, etc. Fizeram parte da coletânea, entre outros: Durval Marcondes, Anita Cabral, Herbert Baldus, Mário Wagner Vieira da Cunha, Lourenço Filho, Virgínia Leone Bicudo, Aniela Ginsberg e Betti Katzenstein. 
método de história de vida, procurando observar como as condições de trabalho $e$ as relações intra-familiares interferiam na vida profissional. $\mathrm{O}$ estudo evidenciou que situações adversas de trabalho, tais como: baixos salários, distância entre a moradia do operário e a indústria, más condições de salubridade acarretavam danos à saúde física e psíquica dos mestres (fadiga, irritação e descontentamento) (Bicudo, 1949:391-394). Bicudo verificou que problemas familiares e conjugais, vivenciados pelos mestres, também se refletiam em seu trabalho na fábrica. Sentimentos como agressividade, ansiedade e hostilidade, tinham sua origem em frustrações infantis, tais como: pais de origem social subalterna, ausentes, agressivos, alcoólatras. Ela sugere, entre outras propostas, melhores salários para os trabalhadores, não obstante a necessidade de um "trabalho" que procure superar a "resistência do patronato" (id.ib.:396-398). A pesquisa de Bicudo encontra-se em consonância com uma perspectiva de reforma social existente na ELSP.

As intersecções entre sociologia e psicologia social adquiriram mais visibilidade no final dos anos 1940, quando ainda se vivia os ecos do Holocausto e a busca de inteligibilidade de um fenômeno inédito na história da humanidade. Estudos de estereótipos, atitudes, caráter nacional foram alguns dos tópicos da agenda de pesquisa em ciências sociais do pós-guerra. Em setembro de 1949, a Organização das Nações Unidas para a Educação, a Ciência e a Cultura (UNESCO) aprovou uma agenda antirracista, sob o impacto do nazismo, da visível persistência do racismo em diversos países e do processo de descolonização africano e asiático. Em junho de 1950, foi inserida no programa da agência internacional a realização de um ciclo de pesquisas sobre as relações raciais no Brasil, país considerado um contra-exemplo em matéria de racismo, em perspectiva comparada com a experiência internacional, notadamente os EUA e a África do Sul do pós-2a ${ }^{a}$ Guerra (Maio, 1999).

Otto Klineberg teve papel relevante como diretor-interino do Departamento de Ciências Sociais e consultor da UNESCO no 
Entrevista Virgínia Leone Bicudo

delineamento da pesquisa sobre relações inter-raciais no Brasil. Ele recomendou à UNESCO que realizasse ampla e diversificada investigação, incluindo regiões tradicionais e modernas no intuito de observar o complexo e matizado padrão de relações raciais no Brasil (Id. Ib:148). Enfatizou a importância da inclusão nas investigações dos aspectos psicossociais e sugeriu quatro nomes: Aniela Ginsberg, Cícero Christiano de Souza, Betti Katzenstein e Virgínia Bicudo. Quanto à última sugestão, em documento endereçado ao etnólogo Alfred Métraux, Chefe do Setor de Estudos sobre Raça do Departamento de Ciências Sociais da UNESCO, Klineberg informou que Virgínia encontrava-se:

na Divisão de Saúde Mental da Secretaria de Educação de São Paulo, trabalhando com Dr. Durval Marcondes. (...) Ela é, em parte, de origem negra, e está muito interessada no problema das relações raciais. Ela escreveu uma dissertação de mestrado muito boa sobre as atitudes dos negros nas relações entre negros $e$ brancos em São Paulo. Isto foi realizado sob a direção de Donald Pierson da Escola Libre (sic) (p.7). ${ }^{23}$

Com essas credenciais, Virgínia Bicudo foi incorporada à equipe do "projeto UNESCO". Dando continuidade ao estudo realizado no mestrado, ela investigou, a partir da coleta de informações de uma amostra significativa do alunado do então curso primário de escolas públicas no município de São Paulo (4.520 escolares), as atitudes raciais na vida escolar. Incluiu na pesquisa entrevistas com familiares de crianças e adolescentes ( 9 a 15 anos) das camadas populares e médias. $\mathrm{O}$ universo delineado

23 "(..) in the Division of Mental Health of the São Paulo School System, working with Dr. Durval Marcondes. (...) She is part Negro in origin, and is very much interested in the problem of race relations. She wrote quite a good master's essay on the attitudes of Negroes in São Paulo to Negro-White relations. This was done under the direction of Donald Pierson of the Escola Libre [sic] (p.7)", in Klineberg, Otto. "Comments on memorandum regarding research on race relations in Brazil", 1/8/1950, p.4, in: Race Questions \& Protection of Minorities. REG 323.1. Part II up to 31/VII/50 (BOX REG 145). UNESCO Archives. 
era composto por: brancos (86,32\%); negros (6,86\%); japoneses $(3,99 \%)$; mulatos $(2,89 \%)$.

Os objetivos da pesquisa eram:

evidenciar os sentimentos e os mecanismos psíquicos de defesa manifestos nas atitudes relacionadas com a cor dos colegas e verificar a influência das relações intra-familiares no desenvolvimento daquelas atitudes (Bicudo, 1955:227228).

Um questionário foi utilizado para aferir as atitudes de rejeição ou de intimidade, aproximação, entre os alunos associando-as à cor da pele, lembrando a escala de distância social de Emory Bogardus (1932).

Ao serem indagados sobre os motivos das atitudes de rejeição, os alunos citaram o fato do colega negro ser "mau aluno, maldoso, mal educado e mau amigo". Cabe destacar que os termos "sujo, porco, pobre, negro ou de outra raça" foram muito pouco utilizados, o que levou Bicudo a constatar "que a rejeição por motivos explicitamente raciais foi mínima. Contudo, ela observou que os sentimentos hostis relacionados com a cor foram mascarados (Bicudo, 1955:244-245). O critério racial só apareceu nitidamente em 18 das 8072 respostas dadas quanto aos motivos de evitação em relação ao colega de classe. Dentre as denominações atribuídas aos negros mais rejeitados encontram-se: "ruim, briguento, mal criado, mal comportado, mal educado, copiador" (Id:Ib:290).

No caso dos familiares entrevistados, os brancos buscam ocultar suas atitudes adversas aos mulatos e negros de várias maneiras. Um repertório de comentários foi acionado: "há bons e maus entre brancos e pretos", "são todos humanos", "o que faz as pessoas diferentes é a educação e a instrução", todavia eles evitariam relações mais próximas em certas situações da vida privada como casamentos com pessoas de cor. Outro grupo se manifestaria francamente contra os negros demonstrando que 
Entrevista Virgínia Leone Bicudo

estes são: "perversos, maus, bêbados, desonestos, vagabundos, ladrões e macumbeiros" (Id:Ib:294).

A participação de Bicudo no "projeto UNESCO" contribuiu para a produção de um conjunto de dados $e$ análises sistematizadas sobre o preconceito e a discriminação racial no Brasil. Com essa pesquisa, ela encerra seu ciclo de estudos sobre as atitudes raciais. Seu envolvimento com a institucionalização da psicanálise a levou definitivamente para outro universo de desafios.

\section{Do Divã da Dra. Koch à institucionalização da psicanálise}

O envolvimento de Bicudo com o ciclo de pesquisas da UNESCO ocorreu simultaneamente as suas atividades na Sociedade Brasileira de Psicanálise de São Paulo, na ELSP e no Serviço de Higiene Mental da Secretaria de Saúde do Estado de São Paulo. Na década de 1950, houve a ampliação das iniciativas de Virgínia no campo da institucionalização da psicanálise no Brasil. Em 1954, por intermédio de Anita Castilho Cabral, foram contratados Virgínia Bicudo, Durval Marcondes, Lygia Alcântara do Amaral e Judith Teixeira Carvalho, pelo Departamento de Psicologia da Faculdade de Filosofia, Ciência e Letras da USP. O objetivo do grupo era expandir a psicanálise no Departamento de Psicologia da USP (Bicudo, 1989:97).

No ano seguinte, Virgínia obteve licença remunerada de seu emprego público como educadora sanitária e viajou a Londres para aprofundar seus conhecimentos psicanalíticos. Durante sua estada na cidade, ela fez análise com Frank Philips, frequentou cursos no Instituto de Psicanálise da Sociedade Britânica e se especializou em psicanálise da criança na Tavistock Clinic, sob a supervisão de Esther Bick (Valladares, 1996). Em 1956, Nosso Mundo Mental, livro organizado a partir do programa da rádio Excelsior, apresentado por Virgínia, e de sua coluna no jornal Folha da Manhã, foi lançado em São Paulo. Trata-se de uma obra 
de divulgação científica utilizando meios de comunicação de massa, algo inédito no campo da psicanálise no país. ${ }^{24}$

Na década de 1960, de volta ao Brasil, após cinco anos de estudos na Inglaterra, Bicudo tornou-se professora e diretora do Instituto de Psicanálise da Sociedade Brasileira de São Paulo criando ainda o Jornal de Psicanálise. Em 1970, dando continuidade a seus esforços em prol da institucionalização da psicanálise no país, ela fundou o Grupo Psicanalítico de Brasília, lecionou na Divisão de Saúde Mental da Universidade de Brasília, abriu consultório e fundou a Revista de Estudos Psicodinâmicos ALTER. No ano seguinte, Virgínia organizou o Instituto de Psicanálise de Brasília. Em 1976, iniciou o curso de Formação de Analistas de Crianças, com a colaboração de Lygia de Alcântara Amaral (Rocha \& Haudenschild, 2004:69). No decorrer das décadas de 1980 e 1990, Virgínia Bicudo participou de Conferências, Jornadas, Encontros e produziu uma vasta obra científica veiculada principalmente em periódicos nacionais na área da psicanálise. $\mathrm{Na}$ última frase da entrevista, ora publicada nos Cadernos Pagu, Virgínia confessou em tom bem humorado: "eu sempre brinco que estreei o divã no Brasil". Ela poderia ter ampliado o leque de evidências que confirmam sua trajetória ímpar, de uma mulher que protagonizou a criação $e$ desenvolvimento de instituições e de produção de conhecimento científico no campo da saúde, das Ciências Sociais e da psicanálise.

Há 15 anos, Virgínia Bicudo me concedeu a entrevista que vem a seguir, na então residência da psicanalista, na Avenida 9 de Julho. Em certo momento da nossa conversa, Virgínia me mostrou orgulhosamente uma foto da turma de formatura do Sr. Teófilo,

${ }^{24} \mathrm{O}$ livro condensa vários estudos sobre a personalidade desenvolvidos por Bicudo em diferentes instituições de ensino: a ELSP, Associação Brasileira de Psicanálise e, principalmente, a Seção de Higiene Mental do Serviço de Saúde Escolar de São Paulo. Ao longo do livro, a autora ilustra seus conceitos teóricos por meio de casos exemplares, que reconstituem problemas familiares e situações cotidianas (Bicudo, 1956). 
Entrevista Virgínia Leone Bicudo

no prestigioso Ginásio do Estado. Ao me lembrar desse encontro, tão cheio de sentidos, eu o associo a uma frase do sociólogo Alberto Guerreiro Ramos: "É preciso não carregar a pele como um fardo". ${ }^{25}$

\section{Entrevista de Virgínia Leone Bicudo a Marcos Chor Maio ${ }^{26}$}

\section{Em Família}

Marcos: Doutora Virgínia, gostaria que a senhora falasse um pouco da sua origem, lugar e data de nascimento.

Virgínia: Data de nascimento? 21 de novembro de 1910, São Paulo, bairro da Luz. Sou filha de Teófilo Júlio Bicudo e Joana Leone Bicudo. Meu pai nasceu em Campinas e ele tinha muito orgulho de ser campineiro. Ele foi criado em casa dos que tinham sido patrões dele. De modo que era muito querido nessa família, dentro da qual ele nasceu. Minha mãe trabalhava também nessa casa. Isso tudo no interior de São Paulo. Eles que me contaram essas coisas [risos]. O que eu sei é que meus avós maternos vieram da Itália. Minha mãe teria 10 anos quando aqui chegaram, $e$ foram então para o interior do estado de São Paulo. Acho que cuidavam de café, não era? Deve ser isso. Sabe, eu nunca pensei como estou pensando agora, primeira vez [risos]. Eu nunca reconstituí, agora eu estou construindo o que ouvi dos meus pais. Eu nunca pus ordem, agora que estou imaginando, assim. Acho que iam lavrar a terra, cultivar. Então eu sei que os imigrantes $e$ meus pais foram para o interior de São Paulo. Meus pais se casaram em 1905.

Marcos: Eles trabalhavam na mesma casa?

${ }^{25}$ A expressão-síntese de Guerreiro Ramos é a epígrafe do livro Fala Crioulo de Haroldo Costa (1982). Guerreiro disse-lhe a frase pessoalmente, conforme depoimento do produtor cultural ao autor (15/06/2010).

${ }^{26}$ Realizada na cidade de São Paulo em 25 de agosto de 1995 (1 hora e 33 minutos). 
Virgínia: Eles se conheceram trabalhando na mesma casa, de gente de recursos. Tinha fazenda e tinha casa em São Paulo.

Marcos: Que tipo de trabalho seu pai fazia?

Virgínia: Acho que era trabalho de empregado doméstico.

Marcos: E quando ele veio para São Paulo, trabalhou em quê?

Virgínia: Veio casado. Aí já tinha vida independente, era funcionário do Estado.

Marcos: Ele se tornou funcionário do Estado?

Virgínia: A própria família para quem ele trabalhou conseguiu colocá-lo no Estado. No Estado, ele trabalhava na Agência Postal. Então ele era agente postal, trabalhava lá dentro. Depois desses primeiros períodos, começou a trabalhar fora, como carteiro. Entregava cartas. Depois, bom... meu pai foi um homem muito interessante. No sentido assim de ambicioso, de subir, subir como gente. $\mathrm{Eu}$ acho que ele conseguiu. Meu pai tem uma história muito bonita. Muito bonita porque foi sempre trabalhador $e$ querendo sempre progredir, mas do ponto de vista psíquico, de inteligência. Então, primeiro ele foi empregado doméstico. De família, assim de recursos. Eu acho que a família veio para São Paulo. Ele veio junto e então conseguiu um emprego público. Viu como é que foi a emancipação dele? De doméstico a emprego público. E o primeiro emprego público que ele teve foi nos Correios e Telégrafos de São Paulo. E aí trabalhou a vida inteira. A ambição dele é que um dia ele ia ser o diretor geral dos Correios de São Paulo. Bom, ele não alcançou esse ponto máximo, mas alcançou ser o diretor geral de uma agência de São Paulo. Quer dizer, ele era um homem muito ambicioso. Ele fez carreira.

Marcos: A senhora me mostrou agora uma foto dele completando o ginásio.

Virgínia: É, ele fez o ginásio.

Marcos: Ele fez o ginásio já dentro dos Correios. 
Entrevista Virgínia Leone Bicudo

Virgínia: Fez o Ginásio do Estado de São Paulo. Acho que foi o melhor ginásio, foi o primeiro ginásio de São Paulo. E ele estava no último ano. ${ }^{27}$

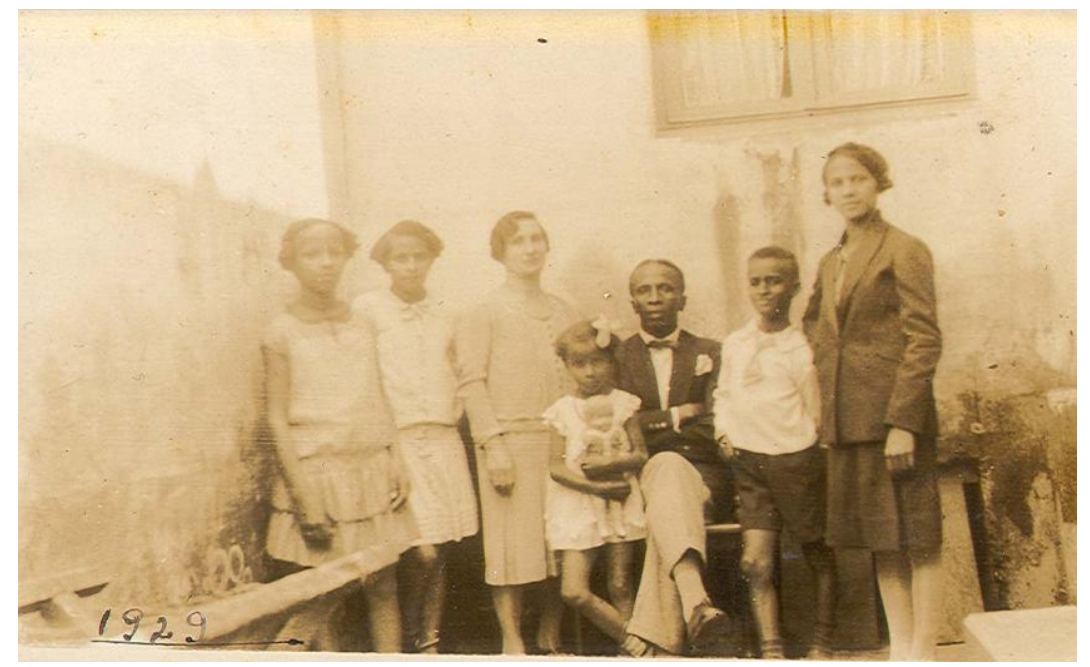

Família de Virginia Leone Bicudo na casa da Vila Economizadora. Da esquerda para a direita vêem-se as irmãs Lourdes e Helena, a mãe, Dona Joana, a irmã Carmem com a boneca, o pai Sr. Teófilo Bicudo, Teófilo Jr. e Virginia. São Paulo, 3 de março de 1929. Fonte: Divisão de Documentação e Pesquisa da História da Psicanálise/ SBPSP.

\section{Discriminação racial}

Virgínia: Olha, vou contar uma coisa tristíssima da história dele. Ele queria fazer universidade. Na época era Curso Superior. E ele queria ir para Medicina. Então estava no sexto ano do ginásio. Veja que homem esforçado, hein? Veio de empregado doméstico que ele era, depois foi subindo e fez o Ginásio do Estado. E quando terminou o Ginásio do Estado naquele ano, ele passava

${ }^{27}$ O Ginásio do Estado de São Paulo é uma tradicional escola pública paulista fundada em 1894. Atualmente tem o nome de Escola Estadual de São Paulo. 
direto para Faculdade de Medicina. Naquele tempo não havia vestibular para Medicina. ${ }^{28}$ Terminava o ginásio e entrava na Medicina ou em qualquer curso superior. Então, o professor que chamava Barros ou Barrinhos, do ginásio do último ano, quando viu que meu pai ia para Faculdade de Medicina, reprovou. Porque ele disse que negro não podia ser médico. Então, meu pai durante 10 anos ficou fazendo o sexto ano para passar e entrar na Medicina. E esse professor que eu não esqueço o nome... Parece que é castigo, Barros, da Física, reprovava.

Marcos: Durante 10 anos?

Virgínia: 10 anos. Meu pai insistiu que queria ir pra Medicina e não conseguiu porque esse homem barrava. Depois desses 10 anos, aí não pôde entrar, porque não tinha mais essa entrada direta do ginásio para Medicina. Aí tinha que fazer vestibular. Aí meu pai desistiu, já tinha a filharada toda. Então ele foi barrado por preconceito. Puro preconceito. Eu quando criança via tudo isso. Eu já existia quando meu pai ficou nessa luta. Eu já ouvia as brigas todas, as decepções que não podia entrar, mas ele tinha que ir. Tudo isso eu vi, acompanhei como criança.

Marcos: Sua mãe era branca, seu pai era negro, trabalhavam numa casa em Campinas e eles se casaram. Teve algum problema?

Virgínia: Não, não. As famílias pelas quais eles trabalhavam, ao contrário, fizeram festa.

Marcos: Certo. Eu estou falando da família italiana. Não teve nenhum tipo de reação da sua mãe branca se casar com seu pai, um negro?

Virgínia: Ah, isso eu não sei. Quando eu nasci, meus avós italianos, todos os meus parentes italianos se davam bem.

Marcos: E se davam bem com a família do seu pai também?

${ }^{28} \mathrm{O}$ pai de Virgínia Bicudo criou um curso pré-vestibular em sua casa com intuito de preparar alunos para entrarem na Faculdade de Medicina de São Paulo (Zingg, 2009). 
Entrevista Virgínia Leone Bicudo

Virgínia: Não, meu pai não tinha família, ele ficou sozinho, todo mundo morreu.

Marcos: E irmãos, ele também não tinha?

Virgínia: Ele tinha um, mas também morreu. Esse irmão eu me lembro. Quando eu era criança. Era um irmão, mas que bebia muito. Então morreu cedo. De tanto beber. Tudo isso é da minha infância que eu via.

Marcos: E eram quantos filhos?

Virgínia: Seis. Dois homens e quatro mulheres. Meus irmãos morreram. As mulheres todas estão vivas.

Marcos: A senhora falou bastante do seu pai, e no caso da sua mãe?

Virgínia: Ela era babá e meu pai era empregado. Então eles se conheceram na casa, onde eles trabalhavam. Se amaram e se casaram [risos].

Marcos: E depois do casamento, sua mãe ficou cuidando da casa?

Virgínia: Bom, depois do casamento, minha mãe não trabalhou fora. Porque aí meu pai fez carreira no funcionalismo público e de diretor dos Correios, que era a ambição dele. Ele ganhou uma agência de São Paulo, que ele foi o diretor. Ela trabalhava para os filhos. Seis filhos.

\section{Vida escolar e infância no Bairro da Luz}

Marcos: E a senhora foi logo para escola ou foi alfabetizada em casa?

Virgínia: Para meu pai todo mundo tinha que ser alfabetizado. E todo mundo foi para escola. Ninguém foi trabalhar. Meu pai escolheu o que havia de melhor. Eu fui para Escola Modelo. ${ }^{29}$ Porque tinha a escola primária comum e tinha a Escola Modelo

${ }^{29}$ A tradicional instituição pública de ensino denominada Escola Modelo Caetano de Campos, situada no bairro da Luz, em São Paulo, foi criada em 1890. Sobre a ideologia das escolas modelos, ver Carvalho, 2002. 
Caetano de Campos. Então começava no Jardim de Infância, Escola Modelo, Primária, depois Escola Complementar e Escola Normal. Então, meu pai já punha os filhos assim, na Escola Modelo Caetano de Campos, entende? Meu pai era um homem de uma ambição para formar... Não era para ganhar dinheiro, mas para educar cem por cento. Então ele punha todos os filhos no que havia de mais promissor para fazer carreira.

Marcos: A senhora disse que nasceu em São Paulo e no bairro da Luz?

Virgínia: É. Era gente humilde, mas com um certo nível. Meu pai sempre defendeu uma apresentação boa. Então a gente estava lá. Era uma travessa da Rua São Caetano ${ }^{30}$, mas muito bem cuidada. Então, eu fui para uma escola que era perto de onde eu morava, mas eu não fiquei lá muito tempo porque tinha que ir para uma escola melhor. Então, meu pai me pôs na Escola Modelo Caetano de Campos. Porque aí já seguia direto para fazer carreira de professora.

Marcos: O bairro que a senhora morava era um bairro constituído basicamente de brancos ou negros?

Virgínia: Era um bairro de brancos. É, eu acho que preto não tinha lá. Acho que tinha só nós. Geralmente era assim, a gente nunca esteve no meio de pretos. Engraçado. Eu nunca notei isso. Eu me lembro da casa em que eu nasci na Luz. Nessa casa morei até os 15, 16 anos. E nasceram todos os outros meus irmãos. Eu sou a segunda. Tem meu irmão primogênito, depois eu. Mas o que eu ia falar disso? Ah, essa questão do preconceito. Onde eu nasci só meu pai era preto, ninguém mais. Eu nunca tive convívio com pretos ou negros. Mas isso não foi eu, eram meus pais [risos]. Eu achei horrivel. Acho que eram eles, meus pais. Começou nos Correios e aí ele foi sempre subindo, e sempre com os brancos.

30 Tratava-se da Vila Economizadora, criada em 1907, pela Sociedade Economizadora Paulista, situada no Bairro da Luz, na Rua São Caetano nº 602 (Medrano, 2006:1-26). 
Marcos: Sempre com os brancos. E, tirando esse fato do professor do sexto ano ginasial que não deixava ele passar por ser negro, seu pai comentava algo sobre o ambiente de trabalho?

Virgínia: Não, não, não. Ele sempre foi prestigiado. Ele sempre teve posição de ascensão.

Marcos: No caso de seus irmãos, havia uns mais claros e outros mais escuros?

Virgínia: Não, tudo a mesma coisa [risos]. A fábrica foi a mesma. É tudo igual. Agora, o que acontece é que meu pai pôs todo mundo para estudar. Ele queria que todo mundo se formasse. Mas o meu irmão mais velho ficou repetindo. Foi para o ginásio $e$ ficava repetindo o ano. Então foi uma luta. Eu me lembro dessa luta em casa. Porque ele repetia, e aí tinha castigo, e aí mamãe chorava. Olha, foi um negócio, para ele fazer os 5, 6 anos de ginásio, foi um inferno.

Marcos: A senhora foi uma boa aluna?

Virgínia: Engraçado isso... porque eu sou a segunda, meu irmão era o mais velho, então eu via as brigas porque meu irmão não estudava e era castigado. E era aquela briga lá em casa, porque ele não estudava. E eu só ouvia, porque ele não estudava $e$ ia ser reprovado. Bom, eu agora vou para escola, primeiro primário. Aí a professora falou assim: "Triângulo". Engraçado que eu guardo até hoje. "Isso aqui é o triângulo. Para estudar geometria". E eu peguei aquilo e... saía da escola e corria, e corria, e corria... Entrei em casa e gritei: "Estou estudando matemática!" [risos]. Porque o que eu ouvia era briga com o meu irmão, que era muito mais velho do que eu. E quando eu vi lá, a professora disse: "Geometria, matemática", eu cheguei em casa: "Eu estudo matemática!" Para dar alegria, porque era um desgaste lá em casa porque meu irmão não estudava matemática. Bom, são as coisinhas engraçadas da infância. Mas então nessa questão de cor. Meu pai e minha mãe, avós, meus avós, tios, do lado do meu pai não tinha ninguém, por isso que não tinha contato com preto, 
com negros. Meu pai era sozinho. Então, era tudo do lado da minha mãe.

Marcos: E seus avós? A senhora teve contato com seus avós?

Virgínia: Assim, da parte da minha mãe? Tive, tive. Ah, minha vida toda, até eles morrerem. Meus avós moravam na Lapa. Só meu pai que morava na Luz, eu, meu pai, minha mãe. Os outros não. Meus avós, da parte da minha mãe, foram para Lapa. Eles tinham uma chácara e a gente ia para lá, todos os domingos.

Marcos: A senhora falou do seu irmão mais velho e os outros irmãos?

Virgínia: Nós somos seis irmãos.

Marcos: E em relação aos outros irmãos?

Virgínia: Olha, a ideia de meu pai era que as pessoas valem pelo estudo, pelo preparo que tem estudando, isso era meu pai. Então, meu pai pôs todos na escola. Meu irmão mais velho foi para o ginásio, mas aí ele repetia.

Marcos: Mas ele acabou se formando, ou não?

Virgínia: O ginásio ele fez.

Marcos: Mas depois não continuou.

Virgínia: Não, fez ginásio à custa de muito castigo. Depois o outro entrou no ginásio, mas não foi adiante, largou. Mas aí meu pai já tinha morrido. $\mathrm{E}$ as mulheres todas foram para escola e se formaram. Todas foram fazer curso de professora, Normal. Todas nós. ${ }^{31}$

\section{O Curso Normal e o Instituto de Higiene}

Marcos: Ninguém foi ser professora?

Virgínia: Não, cada um fez outra coisa depois. Eu nunca fui professora. Eu me formei. Mas em seguida eu já fui para o

${ }^{31}$ De acordo com Zingg (2009), todos os irmãos de Virgínia Bicudo fizeram o ginásio. Apenas ela concluiu ensino superior. Duas de suas irmãs, Lurdes e Helena, se formaram professoras. 
Entrevista Virgínia Leone Bicudo

Instituto de Higiene. Fiz uma outra formação: Educadora Sanitária.

Marcos: A senhora ficou na Escola Modelo Caetano de Campos até o final do Normal?

Virgínia: Até o final do Normal. Depois do Normal... eu precisava ganhar dinheiro, acabava de me tornar professora. Nós fazíamos o curso de professora primária. E ali obtinha uma cadeira no interior. Mas aí meu pai me disse: "Filho meu não vai para o interior". E então, eu fui fazer um outro curso, o de Educadora Sanitária no Instituto de Higiene.

Marcos: Antes de a senhora começar a falar sobre o Instituto de Higiene, gostaria de perguntar quais eram as matérias que a senhora mais gostava no Ginásio? Tinha alguma predileção?

Virgínia: Eu tinha sim. Isso é interessante, logo no início do Ginasial eu me destaquei em duas coisas no curso. Eu me destaquei porque eles que me destacavam. Era Aritmética, chamavam Matemática, Português. As duas, sabe? Eu tinha primeiro lugar na classe. Então eu era sempre pequenininha, menor da classe, mas de nota, eu era a primeira.

Marcos: A senhora gostava da escola?

Virgínia: Gostava. Mas a minha associação eu faço logo com meu pai que valorizava o estudo.

Marcos: Aí a senhora acabou o Normal e entrou para o Instituto de Higiene. Seu pai ainda estava vivo quando...

Virgínia: Estava.

Marcos: Seu pai disse que para o interior nunca, jamais.

Virgínia: Ah, é. Pode formar, mas você não vai para o interior. E eu tinha que começar a carreira de professora no interior.

Marcos: O interior significava atraso ainda, não?

Virgínia: É uma ideia de que a gente ia sofrer. Porque não tinha os recursos que a gente tinha dentro de casa. E ia para fora, no interior para lecionar, para ensinar, mal acomodado. Era 
sofrimento, na minha ideia. Então, o que eu fiz foi fazer algum curso depois desse para me garantir, não precisar ir para o interior. E o curso que tinha depois desse para fazer era Educadora Sanitária, que era um curso dado pela Faculdade de Higiene, junto à universidade. Então tinha curso de Educadora Sanitária, cuja função era cuidar, zelar pela saúde dos escolares.

Marcos: Quantos anos era o curso?

Virgínia: 2 anos.

Virgínia: Em 1932, eu fiz o curso de Educadora Sanitária. ${ }^{32}$ Tive aulas de Higiene Mental, Higiene Escolar, é mais higiene. Paula Souza $^{33}$ dirigia o curso. Ele criou o Instituto de Higiene de São Paulo junto à Universidade de São Paulo. Era outro nível.

Marcos: Tinha matérias de Sociologia?

Virgínia: Não, não tinha. Sociologia eu fiz na Escola de Sociologia. Era só saúde mesmo. Quando eu me formei em Educadora Sanitária, eu fui trabalhar nos grupos escolares para a saúde das crianças. A gente ia assim, nas classes, primeiro ano, segundo ano e organizava, fazia vacina, via quem precisava de óculos, entende? Saúde. Providenciando o que precisava. Não enxerga bem, encaminha para o oculista. Está deficiente físico, então, vai para o médico. Zelava pela saúde da criança. Ah, e com os pais também, contato com os pais. Orientar os pais também na educação, na higiene da criança. Esse foi o trabalho com higiene

32 O currículo abrangia as seguintes disciplinas: Noções de Estatística Vital e de Epidemiologia; Higiene Infantil; Higiene Mental, Social e do Trabalho; Ética, Educação e Administração Sanitária; Princípios e Processos de Enfermagem em Saúde Pública (Rocha, 2003).

33 O médico Geraldo Horácio de Paula Souza (1889-1951) foi o fundador do Instituto de Higiene e da Faculdade de Higiene e Saúde Pública, núcleos que deram origem à atual Faculdade de Saúde Pública da Universidade de São Paulo. Paula Souza realizou diversos trabalhos junto à Fundação Rockefeller no país nas primeiras décadas do século XX. Embasado no modelo norteamericano, ele transformou o Instituto de Higiene de São Paulo em um centro de higiene e saúde pública, voltado ao ensino e a pesquisa acadêmica (Faria, 2006:182). 
Entrevista Virgínia Leone Bicudo

que eu fiz, mas fiquei só um ano. Aí eu já me interessei pelo psíquico. Aí a doutora Koch ${ }^{34}$ chegou.

\section{Marcos: Doutora Koch?}

Virgínia: Adelheid Koch. Psicanalista européia, que veio de Berlim. Logo em seguida ao começo da guerra. Ela chegou em 1939.

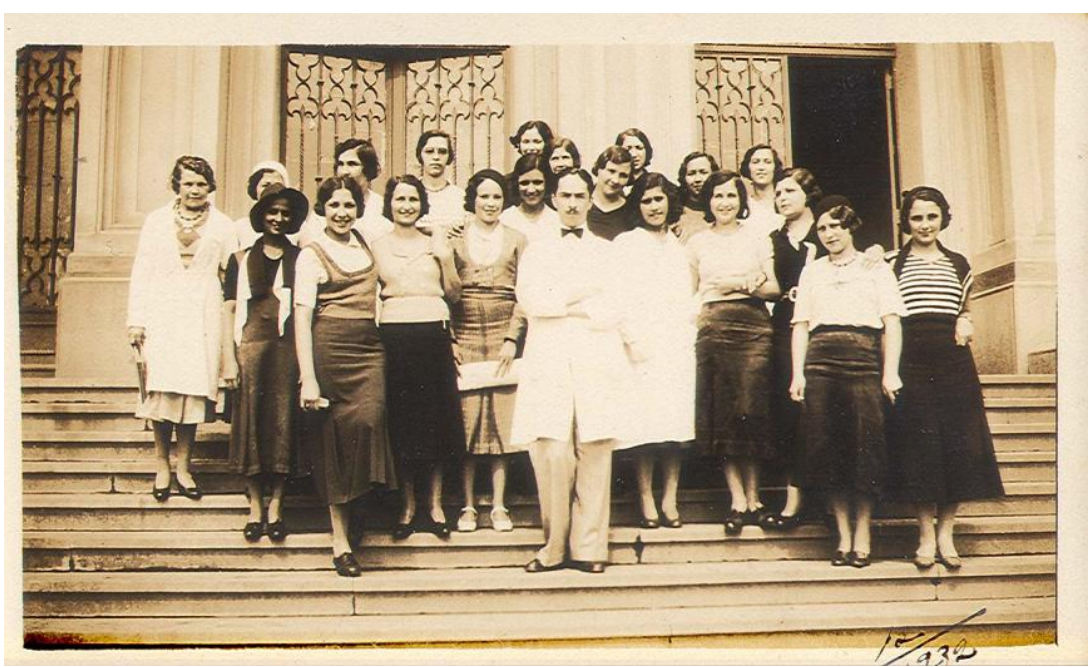

Professor e colegas do Curso de Educadores Sanitários do Instituto de Higiene. Virginia é a primeira da esquerda para a direita, na primeira fila, de vestido escuro e lenço branco no pescoço. São Paulo, 1932.

Fonte: Divisão de Documentação e Pesquisa da História da Psicanálise/ SBPSP

${ }^{34}$ A médica Adelheid Lucy Koch (1896-1980) formou-se pela Universidade de Berlim, especializando-se em psicanálise pelo Instituto de Berlim e, em seguida, passando a ser membro da Sociedade de Psicanálise da mesma cidade (Sagawa, 2002). 
Marcos Chor Maio

\section{Escola Livre de Sociologia e Política}

Virgínia: Aí fui fazer Sociologia na Escola de Sociologia e Política em 1936. Me formei em dezembro de 1932 como Educadora Sanitária. Meu pai faleceu em 1933.

Marcos: Por que a senhora escolheu a Escola de Sociologia e Política?

Virgínia: Ah, porque lida gente com gente... ao passo que Medicina lida com doença de gente. Ao passo que a outra é doença de gente com gente [risos].

Marcos: Isto é ótimo!

Virgínia: [risos] Tá respondido.

Marcos: Na Escola de Sociologia e Política tinha a disciplina Higiene Mental?

Virgínia: Foi o Durval que pôs Higiene Mental. Mas fui eu quem mandei. Na Escola de Sociologia fui eu quem falei: "Põe a cadeira lá" e quem estava lá era ele.

Marcos: Onde é que a senhora conheceu o professor Durval?

Virgínia: Na higiene escolar. Eu conheci o doutor Durval Marcondes, ele era médico escolar e eu era educadora sanitária. E ao mesmo tempo eu estudava Sociologia na Escola de Sociologia. Então, como eu achava que era muito importante Higiene Mental e Durval Marcondes dava Higiene Mental, aí eu começava assim: "Põe Higiene Mental" aqui, "Põe Sociologia" lá. Então eu levei Higiene Mental para a Escola de Sociologia.

Marcos: Fazer a Escola de Sociologia e Política é lidar com gente. Mas não existia outro curso que lidava com gente?

Virgínia: Pois é, porque Sociologia é relação de gente com gente. $\mathrm{E}$ o meu problema assim, psíquico, é que gente com gente não se dá bem. Precisa de uma ciência para ajudar as pessoas a se darem melhor. Isto foi a Escola de Sociologia e Política. Quer dizer, socializar indivíduos. Isso que me chamou a atenção. Esse é o motivo. 
Entrevista Virgínia Leone Bicudo

Marcos: Porque a senhora não foi fazer o curso na Faculdade de Filosofia, Ciências e Letras da USP?

Virgínia: Ah, porque lá eram os grã-finos e eu não era grã-fina. Pensa que eu era boba? [risos] Eu sabia escolher. Eu vi lá, tudo era filho de papai, Almeida Prado e eu não. A Escola de Sociologia é gente operária, é lá que eu vou. É isso. Sabe, a gente tinha esse feeling.

Marcos: Quer dizer que na Escola de Sociologia e Política havia uma diferença...

Virgínia: Mais operários, operariado da ciência. Na Filosofia... como é que era o nome?

Marcos: Faculdade de Filosofia, Ciências e Letras?

Virgínia: Eu disse: "Lá não era o meu lugar".

Marcos: Quando a senhora diz: "Operário da ciência" é no sentido de origem social, de serem pessoas de camadas mais humildes?

Virgínia: Gente mais trabalhadora que coincidia de ser humilde também. Porque quanto menos humilde mais "papai faz".

Marcos: A Escola de Sociologia e Política foi criada por uma elite empresarial $e$ intelectual com o interesse em desenvolver uma sociologia de caráter aplicado. Que tivesse uma aplicação direta, por exemplo, na indústria.

Virgínia: É, mas uma forma indireta de acudir os pequenos. A indústria produzindo meios para que se pudessem trazer os pequenos para cima. Eu senti isso na Escola de Sociologia. Por isso eu fui para Escola de Sociologia. Eu sentia que ali a gente podia ter um apoio para subir, para crescer. E na USP... ali eu sentia que já precisava ter respaldo social. Eu não tinha.

Marcos: Que matérias a senhora mais gostou em seu curso de graduação?

Virgínia: Ah, principalmente Sociologia. Eu estava mais interessada em Sociologia do que em Economia. Eu sempre pensei assim: "Se eu souber como as pessoas se relacionam é 
muito mais importante, porque a Sociologia já decorre de como as pessoas se relacionam". Tinha uma linha americana. Uma coisa que me impressionou muito. Qual foi o nome dele? Professor inglês.

Marcos: Radcliffe-Brown?

Virgínia: Radcliffe-Brown. Esse me impressionou muito.

Marcos: E o professor Pierson? Como era?

Virgínia: Uma pessoa muito chegada à gente. Muito chegado, amigo. Assim que eu via o Pierson. Uma boa pessoa, o Pierson. Ele foi meu professor. Orientador também. Quando escrevia sempre dava para ele ler e comentar. Ele era um professor dedicado.

Marcos: E, nesse período da Escola Livre de Sociologia, a senhora só se dedica a Escola ou exerceu alguma outra atividade?

Virgínia: Nunca fui rica. Tinha que trabalhar para comer. Quando meu pai veio a falecer, eu passei a manter a família, durante um ano. Só depois recebemos o montepio. Nesse um ano então eu já trabalhava na higiene escolar.

Marcos: Qual era o horário da Escola de Sociologia e Política? Tinha um horário fixo?

Virgínia: À noite.

Marcos: E a senhora trabalhava de dia em quê?

Virgínia: Educadora Sanitária.

Marcos: Então a senhora trabalhou mais de um ano em Educadora Sanitária.

Virgínia: Meu pai morreu em 1933. E eu continuei trabalhando de 1933 até 1939.

Marcos: Na sua dissertação de mestrado, a senhora trabalha com pais de alunos ligados a higiene escolar e a um movimento, uma associação de negros.

Virgínia: Na Escola de Sociologia se estudava o problema do negro. 
Entrevista Virgínia Leone Bicudo

Marcos: Há duas referências centrais no seu trabalho que são: Negroes in Bahia, do Pierson, e Marginal Man, do Everett Stonequist.

Virgínia: Estava sob a influência de Donald Pierson.

Marcos: Na época da senhora se falava da Escola de Chicago?

Virgínia: Eu me lembro que Chicago já tinha um destaque. Fui influenciada pelo Pierson. Falavam muito dos negros na Escola de Sociologia.

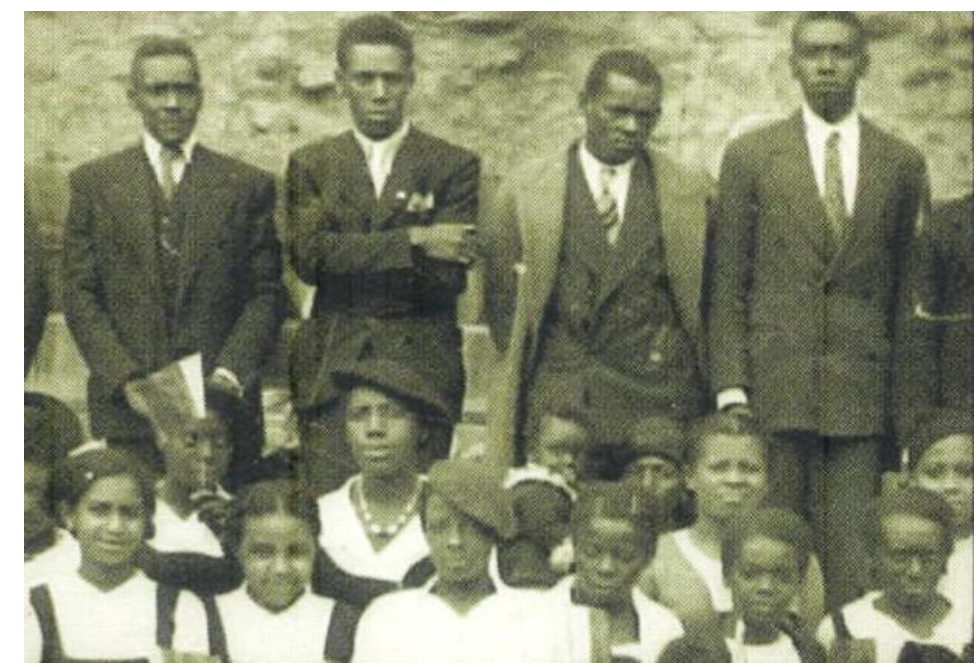

Foto: Reunião de escolares da Frente Negra Brasileira. Década de 1930. Fonte: Arquivo pessoal do historiador Flavio Gomes (UFRJ) 
Marcos Chor Maio

Marcos: Como a senhora veio a participar do projeto UNESCO?

Virgínia: Paulo Duarte. ${ }^{35}$

Marcos: A senhora trabalha com grupos escolares, mais especificamente com o terceiro ano colegial. Como é que são as atitudes favoráveis e desfavoráveis?

Virgínia: Desfavoráveis ao desenvolvimento. Higiene mental.

Marcos: Eram atitudes preconceituosas.

Virgínia: Isso. Mas o campo amplo era o da higiene mental. Bom, foi ainda o Pierson que influenciou.

Marcos: Como a senhora tornou-se professora da Escola? A senhora foi ser assistente do professor Durval Marcondes.

Virgínia: Por causa da minha dedicação. Tinha muita presença, interesse.

Marcos: A senhora trabalhou com uma pesquisa muito interessante sobre os mestres nas fábricas.

Virgínia: Foi. Lenhard que eu conheci, mas depois eu perdi de vista... Rodolfo Lenhard.

Marcos: E é interessante porque o seu trabalho foi realizado numa fábrica, com os mestres. Era um convênio entre a Escola de Sociologia e Política e o Departamento Regional do Serviço Social da Indústria, SESI. Era uma análise psico-social dos mestres. A senhora se lembra dessa pesquisa?

Virgínia: Eu me lembro sim. Agora eu estava pensando, como é que foi meu caminho até ficar só no psíquico. Eu estendi em primeiro lugar para o social, escolar, até me isolar de gente e ficar mais no pensar. Hoje eu estou mais no pensar do que no contato com as pessoas. Então fui do físico para o psíquico.

Marcos: Por que a senhora fez esse trabalho no SESI?

${ }^{35}$ Paulo Duarte foi jornalista, escritor e etnólogo. Ele esteve envolvido no processo de organização e divulgação dos resultados da pesquisa da UNESCO sobre as relações raciais em São Paulo (ver Bastos, 1988). 
Entrevista Virgínia Leone Bicudo

Virgínia: Pois é, tem a ver com higiene mental, não é isso? É um período da higiene mental.

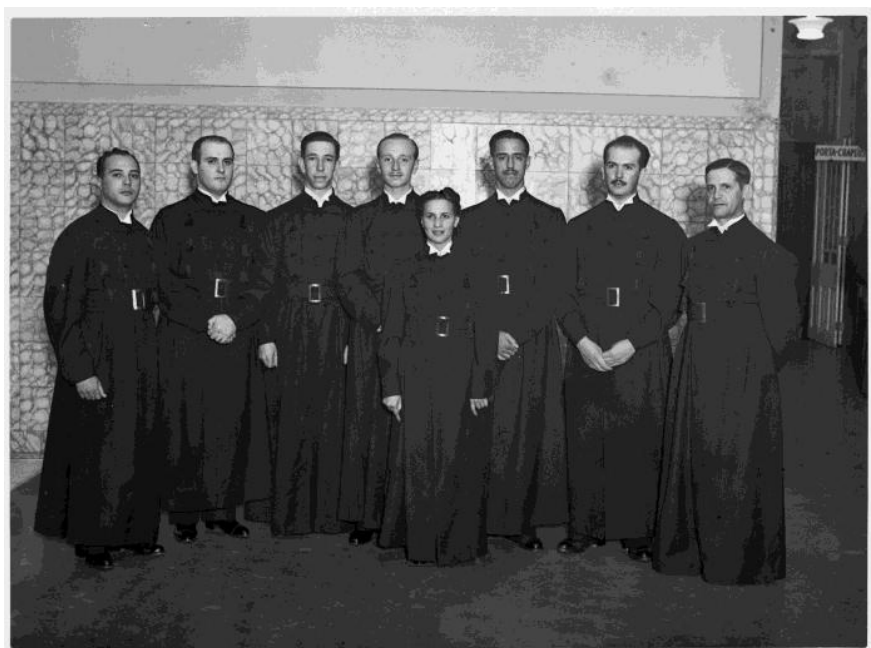

Formandos do bacharelado em Sociologia e Política da ELSP em 1938. Da esquerda para a direita: J. Costa Sobrinho; Antonio Rubbo Müller; J. Siqueira Cunha; Virginia Leone Bicudo; Massimo Guerrine; Olavo Baptista Filho e; Mario G. Pereira; J. Lellis Cardoso. Note-se que entre os oito formandos, Virginia é a única mulher. São Paulo, 1938. Fonte: CEDOC/ FESPSP.

\section{Psicanálise}

Marcos: E aí a senhora vai para Londres?

Virgínia: Foi. Fiquei lá 5 anos.

Marcos: E a senhora foi para Londres com uma bolsa?

Virgínia: A custa própria. Eu falo, ninguém acredita que isso seja possível. E sabe por que eu consegui? Pelos meus vencimentos durante 5 anos, e mensalmente o Governo me pagava a licença. Não é fantástico isso? Vivi dessa licença. Do meu ordenado por mês, por que não?

Marcos: Qual era o cargo que a senhora tinha? 
Virgínia: Era o cargo de Educadora Sanitária. Sabe quem me garantiu o ordenado durante 5 anos? $\mathrm{O}$ nosso presidente Jânio Quadros. Eu recebi durante os 5 anos que eu morei em Londres, mensalmente, os vencimentos. Eu recebi mensalmente meus ordenados. Ele garantiu. Ele acreditou em mim.

Marcos: A senhora negociou a licença diretamente com ele?

Virgínia: Negociei diretamente. Eu estava em Londres, mas aí tinha licença de 1 ano, licença-prêmio. Aí, quando estava acabando eu escrevi para o Jânio Quadros e contei a minha história. E dizia que era importante eu permanecer lá, porque eu trazia coisas importantes para nós. Análise de crianças, por exemplo, levava 5 anos. Então precisava de tempo. Sabe que o Jânio despachou favorável? Formidável, não?

Marcos: E a senhora foi para Londres porque a senhora ia fazer formação analítica lá? É isso?

Virgínia: Eu queria especialização. Formação eu já tinha.

Marcos: E a senhora foi para que instituição lá?

Virgínia: Para a instituição de psicanálise de Londres. Analista didata eu já era. Mas eu tinha consciência de que precisava estudar para fazer jus ao nome. Então fui para lá. Eu tive convívio com grandes psicanalistas, como o Bion. Os maiores psicanalistas. Eu tive, durante 5 anos, a oportunidade de estar junto e me valer do desenvolvimento da psicanálise: Melanie Klein, [Wilfred] Bion, [Donald] Vinikot. Essa turma toda.

Marcos: E aí, quando a senhora retornou ao Brasil, a senhora ficou voltada totalmente para psicanálise?

Virgínia: Eu já era, sempre fui.

Marcos: A senhora é ligada a alguma sociedade?

Virgínia: A Sociedade Brasileira de Psicanálise. Uma coisa que eu sempre fiz e faço, e pretendo fazer é incentivar o desenvolvimento da psicanálise. Eu levei psicanálise para Brasília. Sabe disso? Hoje Brasília tem grupo de psicanalista formado e reconhecido pela Internacional. Eu é que levei, sabe? Então, eu sempre fiz isso. 
Entrevista Virgínia Leone Bicudo

Onde achava que precisava levar a psicanálise, eu levei. Levei para Escola de Sociologia e Política. Antes de ir pra Inglaterra já tinha a cadeira de Psicanálise na Escola de Sociologia e Política.

Marcos: A senhora já estava formada em psicanálise?

Virgínia: Me formei em São Paulo, com a Doutora Koch.

Marcos: Ela veio da Alemanha na década de trinta. A Dra. Koch era de origem...

Virgínia: Alemã. Eu fui a primeira pessoa que usou o divã da Doutora Koch. Mas não é pra contar isso pros outros, viu? Os médicos não vão gostar. Estou fazendo brincadeira agora. Acontece que fui mesmo... A Doutora chegou, todo mundo com receio, com medo... E a Doutora: "Estou organizando aqui, quero ver quem quer...". "Eu quero!" Eu sempre brinco que estreei o divã no Brasil.

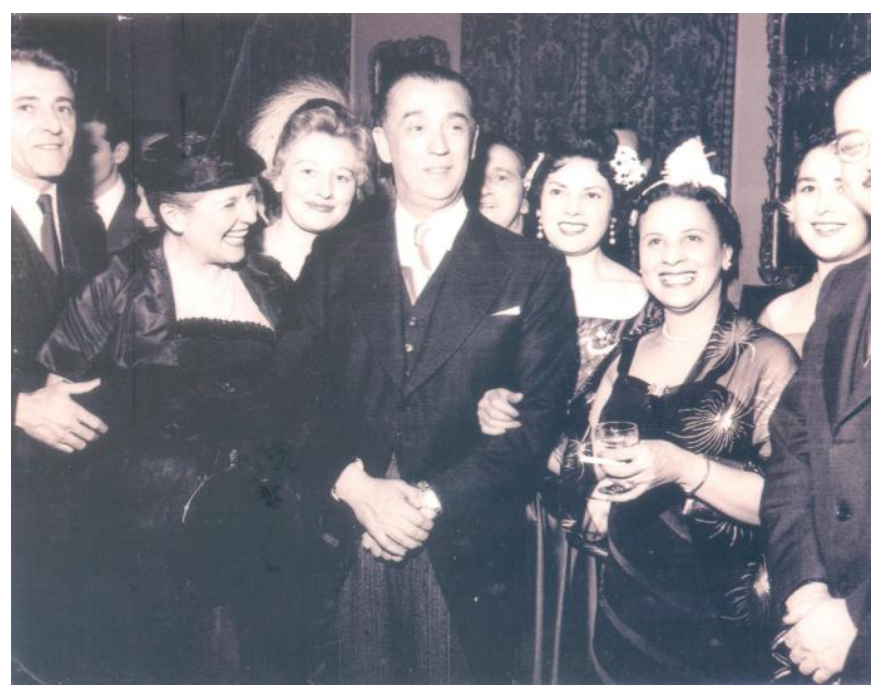

Foto: Virginia Leone Bicudo e o presidente Juscelino Kubitschek em 7 de setembro de 1958 na recepção da embaixada do Brasil em Londres. Fonte: Acervo pessoal de Rosa Zingg 
Marcos Chor Maio

\section{Referências bibliográficas}

ABRÃO, Jorge L.F. Virgínia Bicudo: a trajetória de uma psicanalista brasileira. São Paulo, Arteciência, 2010.

ANDREWS, George Reid. Blacks and Whites in São Paulo, Brazil, 18881988. Madison, University of Wisconsin Press, 1991.

AZEVEDO, Nara \& FERREIRA, Luiz Otávio. Modernização, políticas públicas e sistemas de gênero no Brasil: educação e profissionalização feminina entre as décadas de 1920 e 1940. Cadernos Pagu (27), Campinas-SP, Núcleo de Estudos de Gênero - Pagu/Unicamp, 2006, pp.217-220.

BASTIDE, Roger; FERNANDES, Florestan. Relações Raciais entre negros $e$ brancos em São Paulo. São Paulo, Editora Anhembi, 1955.

BASTOS, Élide Rugai. Um Debate sobre a Questão do Negro no Brasil. São Paulo em Perspectiva, vol. 2, n 2, 1988, pp. 20-26.

Bicudo, Virgínia Leone. Atitudes Raciais de Pretos e Mulatos em São Paulo. Edição organizada por Marcos Chor Maio. São Paulo, Editora Sociologia e Política, 2010.

. "Já fui chamada de charlatã" (Depoimento a Cláudio João Tognolli). Folha de São Paulo, 2004, p. 6.

. Memória e Fatos. Revista IDE, nº 18, São Paulo, 1989.

. Nosso Mundo Mental. Instituição Brasileira de Difusão Cultural, 1956.

. Atitudes dos Alunos dos Grupos Escolares em relação com a Cor dos seus Colegas. In: BASTIDE, Roger; FERNANDES, Florestan. Relações Raciais entre negros e brancos em São Paulo. São Paulo, Editora Anhembi, 1955.

Contribuição ao estudo das condições de trabalho e da personalidade de mestres de indústria em São Paulo. Sociologia, vol. 11, no 3, 1949, pp.381-399.

- Atitudes Raciais de Pretos e Mulatos em São Paulo. Sociologia, vol. 9, n 3, 1947, pp. 196-219. 
Entrevista Virgínia Leone Bicudo

Estudo de atitudes raciais de pretos e mulatos de São Paulo. Dissertação de Mestrado, Escola Livre de Sociologia e Política, São Paulo, 1945.

Serviços Sociais Psiquiátricos. Boletim do Serviço Social dos Menores, vol. 2, n. 3, 1942a, pp. 21-26.

. Importância da Higiene Mental Para A Infância. Boletim do Serviço Social dos Menores, vol.2, n.2, 1942b, pp. 41-47.

- A visitadora social psiquiátrica e seu papel na higiene mental da criança. Revista de Neurologia e Psiquiatria de São Paulo, vol. 7, nº 6, 1941, pp.293-298.

BogARDUS, Emory. A Social Distance. Sociology and Social Research, 17, 1933, PP. 265-271.

CANDiota, Luiz Roberto S. E Myrna Pia FaVILli. AdivinHe QUem VEM PARA JANTAR? UMA CONVERSA COM A PROF. VIRGÍNIA L. BiCUdO. REVISTA IDE, ANO 3, NO. 4, P. 7-13.

CARVAlHo, Marta Maria Chagas de. A República, a Escola e os Perigos do Alfabeto. In: COELHO PRADO, Maria Ligia \& VIDAL, Diana Gonçalves. (orgs.) À Margem dos 500 anos: reflexões e irreverentes. São Paulo, Edusp, 2002.

CASTRO, Maria Antonieta. A Influência da Educação Sanitária na Redução da Mortalidade Infantil. Primeiro Congresso Brasileiro de Eugenia, 1929, p. 3 (Acervo do Setor de Antropologia Biológica do Museu Nacional/Mast).

CAVAlCANTI, Maria Laura V.C. Oracy Nogueira e a antropologia no Brasil: O estudo do estigma e do preconceito racial. Revista Brasileira de Ciências Sociais, vol.11, 1996, pp.5-28.

CosTA, Haroldo. Fala, Crioulo. Rio de Janeiro, Editora Record, 1982.

COSTA PINTO, Luiz de Aguiar. O Negro no Rio de Janeiro: relações de raça numa sociedade em mudança. São Paulo, Companhia Editora Nacional, 1953.

DAMASCENO, Janaína. Estudo de atitudes e preconceito racial na obra de Virgínia Leone Bicudo. In Cone: I Prêmio Construindo a Igualdade Racial. São Paulo, Prefeitura Municipal, 2010, pp. 165-174. 
DuARTE, Luiz Fernando Dias; Russo, Jane; VenÂNCIO, Ana Teresa A. (orgs.) Psicologização no Brasil: atores e autores. Rio de Janeiro, Contracapa, 2005.

FACCHINETTI, Cristiana. Deglutindo Freud: sobre a digestão do discurso psicanalítico no Brasil. Tese de Doutorado em Teoria Psicanalítica, UFRJ, 2001.

FARIA, Lina. Saúde e Política. A Fundação Rockefeller e seus parceiros em São Paulo. Rio de Janeiro, Editora Fiocruz, 2007.

. Educadoras Sanitárias e Enfermeiras de Saúde Pública: Identidades Profissionais em construção. Cadernos Pagu (27), Campinas-SP, Núcleo de Estudos de Gênero - Pagu/Unicamp, 2006, pp.173-212.

FARIS, Ellsworth. The concept of social attitudes. In: The nature of human nature. New York/London, MacGraw-Hill, 1937.

HoCHMAN, Gilberto; LIMA, Nísia \& MAIO, Marcos Chor. The path of eugenics in Brazil: Dilemmas of miscegenation. In: BASHFORD, Alison \& LEVINE, Philippa (editors).The Oxford Handbook of the History of Eugenics. Oxford University Press, 2010, pp.493-510.

KANTOR, Iris; MACIEL, Débora; SIMÕES, Julio Assis. A Escola Livre de Sociologia e Política: anos de formação: 1933-1953. São Paulo, Editora da FESPSP, 2001.

KLINEBERG, Otto. Psicologia Moderna. Rio de Janeiro, Livraria Editora Agir, 1953.

. Social Psychology. New York, Henry Holt and Company, 1940, pp.346-347.

LimONGI, Fernando. A Escola Livre de Sociologia e Política de São Paulo. In: MiCELI, Sergio. História das Ciências Sociais no Brasil, vol.1. São Paulo, Vértice/ IDESP, 1989, pp.217-234.

MAIO, Marcos Chor. A História do Projeto UNESCO: estudos raciais e ciências sociais no Brasil. Rio de Janeiro, Tese de Doutorado em Ciência Política, IUPERJ, 1997. 
Entrevista Virgínia Leone Bicudo

. O Projeto UNESCO e a agenda das ciências sociais no Brasil dos anos 40 e 50. Revista Brasileira de Ciências Sociais, vol. 14, nº 41, 1999.

O racismo no microscópio: Oracy Nogueira e o Projeto UNESCO. Estudios Interdisciplinarios de America Latina y el Caribe, vol. 19, 2008, pp. 35-52.

. Relações Raciais e Desenvolvimento na Sociologia de Costa Pinto. In: BotelHO, André e SCHWARCZ, Lilia Moritz (orgs.) Um Enigma chamado Brasil. São Paulo, Companhia das Letras, 2009, pp. 324-337.

. A contribuição de Virginia Leone Bicudo aos estudos sobre as relações raciais no Brasil. In: BICUDO, Virginia Leone. Atitudes Raciais de Pretos e Mulatos em São Paulo. Edição organizada por Marcos Chor Maio. São Paulo, Editora Sociologia e Política, 2010.

MEDRANO, Ricardo Hernán. Comparação de alguns elementos do traçado urbano nas cidades de São Paulo e Buenos Aires, na virada do século XIX para o XX. Cadernos de Pós-Graduação em Arquitetura e Urbanismo, vol. 6, n 1, 2006.

MEYER, Luiz. A Filha de Teófilo. IN: SBPS - In Memoriam - Virgínia Leone Bicudo (1910-2003); Yutaka Kubo (1917-2003); Adelheid Lucy Koch (1896-1980). Sociedade Brasileira de Psicanálise de São Paulo, 2004, pp. 17-19.

Nogueira, Oracy. Atitude desfavorável de alguns anunciantes de São Paulo em relação a seus empregados de cor. Sociologia (4), 4, São Paulo, 1942.

- Vozes de Campos de Jordão: Experiências Sociais e Psíquicas de Tuberculoso Pulmonar no Estado de São Paulo. $2^{\mathrm{a}}$. edição organizada por Maria Laura Viveiros de Castro Cavalcanti. Rio de Janeiro, Editora Fiocruz, 2009 [1950].

Relações Raciais No Município de Itapetininga. In: BASTIDE, R. \& FERNANDES, F. (orgs.) Relações Raciais entre Negros e Brancos em São Paulo. São Paulo, Editora Anhembi, 1955.

PARK, Robert. E. Human Nature, Attitudes and the Mores. In: YounG, Kimball. Social Attitudes. New York, Henry Holt, 1931. 
PIERSON, Donald. Negroes in Brazil: A study of race contact at Bahia. Chicago, University of Chicago Press, 1942.

Brancos e Pretos na Bahia: estudo de contato racial. $2^{\text {a }}$ Ed. São Paulo, Companhia Editora Nacional, 1971, [1945].

ROCHA, Teresa \& HAUDENSCHILD, Leite. Modernismo, Mulher e Psicanálise. SBPS - In Memoriam - Virgínia Leone Bicudo (19102003); Yutaka Kubo (1917-2003); Adelheid Lucy Koch (1896-1980). Sociedade Brasileira de Psicanálise de São Paulo, 2004, pp.63-73.

RocHA, Heloísa H. P. A higienização dos costumes: Educação escolar e saúde no projeto do instituto de higiene de São Paulo (1918-1925). São Paulo/Campinas, FAPESP/Mercado das Letras, 2003.

SAGAWA, Roberto Yutaka. Durval Marcondes. Rio de Janeiro/Brasília-DF, Imago Ed/CFP, 2002.

SANDLER, Paulo César. Tia Virgínia e o Desenvolvimento: algumas memórias para o futuro. In Memoriam, Virgínia Leone Bicudo, Yutaka Kubo, Adheleid Koch. Sociedade Brasileira de Psicanálise de São Paulo, 2004, p. 28-43.

SILVA, Márcia Regina Barros da. Estratégias da Ciência: a História da Escola Paulista de Medicina (1933-1956). São Paulo, EUSF, 2003.

STONEQUIST, Everett. The Marginal Man. New York, Charles Scribner's Sons, 1937.

THOMAS, William \& ZNANIECKI, Florian. The Polish Peasant in Europe and America. Chicago, The University of Chicago Press, 1918.

VALLADARES, Sílvia. Entrevista com Virgínia Bicudo em 23/08/1991. ALTER - Jornal de Estudos Psicodinâmicos, vol XV, n 1, 1996.

VILHENA, Luís Rodolfo. África na tradição das Ciências Sociais no Brasil. In: VILHENA, L. R. Ensaios de Antropologia, Rio de Janeiro, Ed. da UERJ, 1997. 